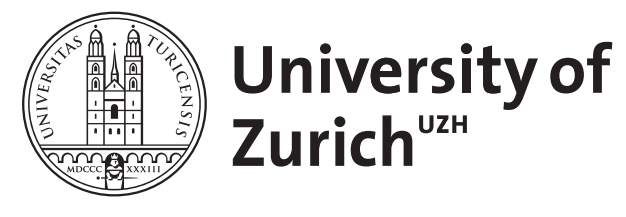

\title{
Selfish and Indoctrinated Economists?
}

Frey, Bruno S ; Meier, Stephan

\begin{abstract}
Many people believe that economists in general are more selfish than other people and that this greater selfishness is due to economics education. This paper offers empirical evidence against this widely held belief. Using a unique data set on giving behaviour in connection with two social funds at the University of Zurich, it is shown that economics education does not make people act more selfishly. Rather, this natural experiment suggests that the particular behaviour of economists can be explained by a selection effect
\end{abstract}

DOI: https://doi.org/10.1007/s10657-005-5425-8

Posted at the Zurich Open Repository and Archive, University of Zurich ZORA URL: https://doi.org/10.5167/uzh-156103

Journal Article

Published Version

Originally published at:

Frey, Bruno S; Meier, Stephan (2005). Selfish and Indoctrinated Economists? European Journal of Law and Economics, 19(2):165-171.

DOI: https://doi.org/10.1007/s10657-005-5425-8 


\title{
Selfish and Indoctrinated Economists?
}

BRUNO S. FREY*

bsfrey@iew.unizh.ch

STEPHAN MEIER

smeier@iew.unizh.ch

Institute for Empirical Economic Research, University of Zurich, Bluemlisalpstrasse, 10, 8006 Zurich, Switzerland

\begin{abstract}
Many people believe that economists in general are more selfish than other people and that this greater selfishness is due to economics education. This paper offers empirical evidence against this widely held belief. Using a unique data set on giving behaviour in connection with two social funds at the University of Zurich, it is shown that economics education does not make people act more selfishly. Rather, this natural experiment suggests that the particular behaviour of economists can be explained by a selection effect.
\end{abstract}

Keywords: economists, public good, giving behaviour, education, selection

JEL Classification: A13, A20, H41

\section{What are economics students like?}

Students of economics are often said to behave more selfishly than other people, and mostly laboratory evidence exists to support this claim. ${ }^{1}$ But it is possible that students play the equilibrium learned in their economics classes, but don't apply it to real life situations. We use a large data set of more than 96,500 observations to study the behaviour of economics students in a natural setting. This data set allows us to analyse whether a possible difference in behaviour is due to the indoctrination of economic education or due to self-selection.

\section{The data}

Each semester, students at the University of Zurich have to decide whether they want to contribute to two official social funds, in addition to paying the compulsory tuition fee. On the official letter for renewing their registration, the students are asked whether they want to voluntarily donate CHF 7.- (about US\$ 4.20) to a fund which offers cheap loans to needy students and/or CHF 5.- (about US\$ 3 ) to a second fund supporting foreigners who study at the University of Zurich. Our data take into account the decisions of 28,586 students over a period of five semesters (winter semester 1998/99 up to and including the winter semester 2000/2001). The students decide an average 3.4 times (depending on the number of semesters attended), generating a total of 96,783 observations.

${ }^{*}$ Corresponding author. 
Table 1. Percentage of economists and non-economists who contribute to the two social funds (University of Zurich 1998-2000).

\begin{tabular}{lccc}
\hline & Economists & Non-economists & Total \\
\hline Contribution to at least one fund & 61.80 & 68.65 & 67.95 \\
& $(6072)$ & $(59694)$ & $(65766)$ \\
Contribution to foreigner fund only & 4.14 & 4.46 & 4.43 \\
& $(407)$ & $(3879)$ & $(4286)$ \\
Contribution to loans fund only & 2.79 & 2.35 & 2.39 \\
& $(274)$ & $(2042)$ & $(2316)$ \\
Contribution to both & 54.87 & 61.84 & 61.13 \\
& $(5391)$ & $(53773)$ & $(59164)$ \\
Total & 100.00 & 100.00 & 100.00 \\
& $(9825)$ & $(86958)$ & $(96783)$ \\
\hline
\end{tabular}

Data source: Compiled from data provided by the accounting department of the University of Zurich.

Students of economics at the University of Zurich undertake a basic study of about 2 years. After passing an exam, they enter the main stage of their studies and have to choose between political or business economics. After graduating, the students may then take up their $P h D$ study. The organisation of the study allows to control for different levels of economics knowledge.

\section{Analysis and results}

Table 1 seems to indicate that economists are more selfish than other students. 61.8 percent of the economic students (political and business economists) contribute to at least one of the funds, compared to 68.7 percent of the students with other majors.

In the following sections, these patterns are tested, controlling for the gender and age structure of the different groups. Moreover, the exten of economic knowledge of the students is controlled for.

\section{Is there a selection effect?}

To distinguish between the selection and the indoctrination hypothesis, we look at the decision of whether to contribute or not to a social fund when first starting university (freshmen). Differences between students of various disciplines at the very beginning of their studies (without having been to a single lecture in economics) support the selection hypothesis. We control for economic knowledge acquired at high school, the main source of pre-university economics training. The dummy variable pre-university knowledge equals 1 if the students attended a high school with an economic orientation and 0 otherwise.

Table 2 presents the results of a probit analysis. The dichotomous dependent variable equals 1 if the student contributes to at least one fund, and equals 0 if the student decides not to give any money at all. Throughout the analysis, we look at the minimum contribution ('to 
Table 2. Contribution of economists and non-economists (University of Zurich 1998-2000 dichotomous dependent variable: 'Contribution to at least one fund' $=1$ probit estimates).

\begin{tabular}{|c|c|c|c|}
\hline Variable & Coefficient & $Z$-value & Marginal effect (\%) \\
\hline Economist $(1=$ economist $)$ & $-0.082^{* *}$ & -3.455 & -2.9 \\
\hline \multicolumn{4}{|l|}{ Stages of study } \\
\hline Freshmen & $-0.088^{* *}$ & -4.254 & -3.1 \\
\hline Freshman* economist & -0.022 & -0.413 & -0.7 \\
\hline Main stage & $0.112^{* *}$ & 8.697 & 4.0 \\
\hline Main stage* economist & $-0.192^{* *}$ & -6.152 & -6.9 \\
\hline Ph.D. & -0.006 & -0.346 & -0.2 \\
\hline Ph.D.* economist & $0.128^{* *}$ & 2.599 & 4.6 \\
\hline Pre-university knowledge & $-0.109^{* *}$ & -9.576 & -3.9 \\
\hline \multicolumn{4}{|l|}{ Control variables } \\
\hline Age 26-30 & -0.006 & -0.488 & -0.2 \\
\hline Age $31-35$ & $0.188^{* *}$ & 11.021 & 6.7 \\
\hline Age $36-40$ & $0.363^{* *}$ & 16.165 & 12.9 \\
\hline Aged over 40 & $0.526^{* *}$ & 21.552 & 18.7 \\
\hline Gender $($ female $=1)$ & $-0.030^{* *}$ & -3.439 & -1.1 \\
\hline Nationality $($ foreigner $=1$ ) & $-0.109^{* *}$ & -8.233 & -3.9 \\
\hline Number of semesters & $-0.046^{* *}$ & -23.034 & -1.6 \\
\hline (Number of semesters) $^{2}$ & $0.001^{* *}$ & 13.729 & 0.02 \\
\hline Period 2 (summer semester 1999) & $0.076^{* *}$ & 5.599 & 2.7 \\
\hline Period 3 (winter semester 99/00) & $0.138^{* *}$ & 10.466 & 4.9 \\
\hline Period 4 (summer semester 2000) & $0.134^{* *}$ & 9.890 & 4.8 \\
\hline Period 5 (winter semester 00/01) & $0.174^{* *}$ & 13.172 & 6.2 \\
\hline Constant & $0.670^{* *}$ & 40.382 & \\
\hline$N$ & 96,783 & & \\
\hline Log likelihood & -59461.91 & & \\
\hline
\end{tabular}

Notes: Reference group consists of 'non-economists', 'basic study', 'without pre-university economic knowledge', 'aged below 26', 'male', 'Swiss', 'semester 1998/99'.

Level of significance: ${ }^{*} 0.01<p<0.05,{ }^{* *} p<0.01$.

Data source: Compiled from data provided by the accounting department of the University of Zurich.

at least one of the funds'). ${ }^{2}$ Control variables are personal factors (age, gender, nationality and the numbers of semesters studied at the University of Zurich) and dummy variables for the semester/year in question.

The first part of Table 2 suggests that a selection effect indeed exists. Students of economics in the broad sense (students cannot choose between business and political economics until they reach the main stage of their studies) donate less to the funds compared to non-economics students. The probability that an economist contributes to one or both of the funds is about 3 percentage points less than for a non-economist. To show that this 
lower willingness to contribute exists at the very beginning of the studies, the variable for economists has to be interpreted along with "being a freshman in economics" (freshman economist). The results suggest that already when the very first decision is made whether to contribute or not (it happens before the first lecture in economics), economics students act more selfishly than non-economists do.

\section{Is there an indoctrination effect?}

The more students of economics learn about the Prisoner's Dilemma Game, the more they become aware that it is "rational" not to contribute. For students not familiar with economic theory, such a decline in cooperation should not take place. If the difference in giving behaviour between the students of economics and the other disciplines increases with each additional semester, the indoctrination hypothesis is not rejected. In order to capture specific knowledge in economics, we compare the behaviour of the students at each stage of their studies. The reference group consists of non-economists in the basic stage of their studies. The results in Table 2 provide an inconsistent picture with respect to the indoctrination effect: Moving from the basic stage to the main stage of University education raises students' readiness to help other students financially by 4.0 percentage points. The coefficient on the dummy for Main stage Economist measures the differences between economists and non-economists when entering the main stage, and hence serves as a test for possible indoctrination effects. For economics students entering the main stage of their studies, the probability of contributing to the fund is reduced by 6.9 percentage points-in addition to the general effect for entering the main stage. But this result does not necessarily indicate the impact of indoctrination, because the probability of contributing increases for doctoral students in economics, while the willingness to donate decreases for doctoral students in other disciplines. If indoctrination really influences the behaviour of students, the effect should be strongest at the doctoral level, where the students have absorbed the largest amount of economics teaching.

Compared to students in the basic stage, students in the main stage of their studies may possibly reflect the selection process that has taken place because a high number of students do not pass the exam enabling them to enter the main stage. The same argument can be raised with respect to $\mathrm{Ph}$.D. students, who certainly differ in many respects from students working only for their Masters Degree. To eliminate a possible sample selection bias, we tested the indoctrination effect in a conditional logit model, with personal fixed effects using the panel structure of the data. Thus, unobserved personal characteristics are held constant. The estimates do not support a negative effect of economics education on giving and are therefore not shown here, so a selection bias can be excluded. The possible indoctrination effects of Table 1 must therefore be due to unobserved heterogeneity.

\section{Behaviour of students of political and business economics}

Table 3 focuses on the differences in contributing to the funds between the two types of students of the economic sciences, between "political economists" on the one hand and "business economists" on the other hand. Students are allowed to choose between the 
Table 3. Contribution of political and business economists (University of Zurich 1998-2000) dichotomous dependent variable: 'Contribution to at least one fund' $=1$.

\begin{tabular}{|c|c|c|c|c|c|}
\hline \multirow[b]{2}{*}{ Variable } & \multicolumn{3}{|c|}{$\begin{array}{c}\text { Model I } \\
\text { Probit estimate }\end{array}$} & \multicolumn{2}{|c|}{$\begin{array}{c}\text { Model II } \\
\text { Conditional fixed effect logit }\end{array}$} \\
\hline & Coefficient & $Z$-value & $\begin{array}{l}\text { Marginal } \\
\text { effect }(\%)\end{array}$ & Coefficient & $Z$-value \\
\hline Economist (in the broad sense) & $-0.103^{* *}$ & -4.794 & -3.7 & & \\
\hline \multicolumn{6}{|l|}{ Stages of study } \\
\hline Freshmen & $-0.091^{* *}$ & -4.461 & -3.3 & $-0.421^{* *}$ & -6.265 \\
\hline Freshman* economist & -0.001 & -0.018 & -0.03 & $0.400^{*}$ & 2.532 \\
\hline Main stage & $0.106^{* *}$ & 8.406 & 3.8 & 0.060 & 0.839 \\
\hline Main stage* political economist & 0.088 & 1.402 & 3.1 & 0.864 & 1.652 \\
\hline Main stage* business economist & $-0.213^{* *}$ & -6.788 & -7.6 & 0.103 & 0.575 \\
\hline Ph.D. & -0.008 & -0.430 & -0.3 & -0.198 & -1.199 \\
\hline Ph.D.* political economist & $0.178^{*}$ & 2.099 & 6.3 & 0.473 & 0.377 \\
\hline Ph.D. * business economist & 0.099 & 1.733 & 3.5 & 0.341 & 0.430 \\
\hline $\begin{array}{l}\text { Pre-university economic } \\
\text { knowledge }\end{array}$ & $-0.109^{* *}$ & -9.568 & -3.9 & & \\
\hline \multicolumn{6}{|l|}{ Control variables } \\
\hline Age & & & & $0.107^{*}$ & 2.329 \\
\hline Age $26-30$ & -0.007 & -0.568 & -0.3 & & \\
\hline Age $31-35$ & $0.188^{* *}$ & 11.046 & 6.7 & & \\
\hline Age $36-40$ & $0.363^{* *}$ & 16.164 & 12.9 & & \\
\hline Age over 40 & $0.526^{* *}$ & 21.556 & 18.7 & & \\
\hline Gender (female $=1)$ & $-0.029^{* *}$ & -3.354 & -1.0 & & \\
\hline Nationality (foreigner $=1$ ) & $-0.109^{* *}$ & -8.256 & -3.9 & & \\
\hline Number of semesters & $-0.046^{* *}$ & -23.049 & -1.6 & -0.039 & -1.566 \\
\hline$(\text { Number of semesters) })^{2}$ & $0.001^{* *}$ & 13.739 & 0 & & \\
\hline Period 2 (summer semester 1999) & $0.077^{* *}$ & 5.698 & 2.8 & & \\
\hline $\begin{array}{l}\text { Period } 3 \text { (winter semester } \\
\text { 1999/00) }\end{array}$ & $0.140^{* *}$ & 10.635 & 5.0 & & \\
\hline Period 4 (summer semester 2000) & $0.136^{* *}$ & 10.032 & 4.9 & & \\
\hline $\begin{array}{l}\text { Period } 5 \text { (winter semester } \\
\text { 2000/01) }\end{array}$ & $0.176^{* *}$ & 13.356 & 6.3 & & \\
\hline Constant & $0.672^{* *}$ & 40.639 & & & \\
\hline$N$ & 96,783 & & & 29,874 & \\
\hline Log likelihood & -59456.66 & & & $\begin{array}{c}-11148.81 \\
\left(\mathrm{LR} \mathrm{chi}^{2}\right) 100.48\end{array}$ & \\
\hline
\end{tabular}

Notes: Reference group consists of 'non-economists', 'basic study', 'without pre-university economic knowledge', 'aged below 26', 'male', 'Swiss', 'semester 1998/99'.

Level of significance: ${ }^{*} 0.01<p<0.05,{ }^{* *} p<0.01$.

Data source: Compiled from data provided by the accounting department of the University of Zurich. 
two economics majors only when entering the main stage of their studies, i.e. after they pass the exams concluding the basic stage of their studies (after approximately two years). Most prior studies (e.g., Carter and Irons, 1991) have concentrated exclusively on political economists. The analysis presented here allows us to distinguish between the different types of economics students and include those who study business economics.

As can be seen in Table 3, political economists differ from other students to the same extent as when they started University. The effect of political economists entering the main stage (Main stage Political Economist) is positive. Thus, the differences between economists and non-economists even decreases, but this effect is not statistically significant. In contrast, the probability of business students contributing to the social funds is - in addition to the general effect-over 7 percentage points lower in the main stage than in the basic study. The results do not support the effect of education in economics, because political economists do not show any (statistically significant) behavioural differences from non-economics students. But the paper-as well as prior studies - is primarily interested in the behaviour of political economists because they study economic theory most intensively. Thus, an alleged indoctrination effect should be the greatest in this group. Again we ran a conditional fixed-effect logit model (model II in Table 3) to control for unobserved heterogeneity. The results support the conclusion that economics education does not have a negative impact on the willingness to contribute.

As students can only choose between studying political or business economics after the initial 2 years, we do not know if the general effect of Economist (in the widest sense) has to be attributed to political or business economists. But the five semesters enable us to observe how students, who later chose to study either political or business economics, behaved in their basic study. The raw data is already convincing: among business economists, whose behaviour we know from the basic study, 61 percent donated money to at least one fund. In contrast, 73 percent of political economists contributed in the basic stage to at least one fund. This suggests that the selection effect identified is almost entirely due to business students.

\section{Conclusions}

The analysis of the actual behaviour of the students with respect to donating money to a fund as a pure public good allows us to draw three conclusions:

(i) Political economists' willingness to donate money does not diminish by studying economic theory;

(ii) The students of business economics give significantly less than other students;

(iii) The lower contribution of business economists, compared to other students, is due to self-selection rather than indoctrination.

The conclusions are important for two quite different reasons:

- Political economists need not fear that they have a negative effect on students' behaviour with respect to altruistic giving. The students and, in particular, the graduates studying for 
a doctoral degree, well understand that political economics does not offer any normative advice with respect to giving.

- The charge often made against political economists, that they produce the type of selfish homo oeconomicus they assume in their theories, is therefore unfounded.

\section{Notes}

1. Marwell and Ames (1981), Carter and Irons (1991), Frank, Gilovich and Regan (1993, 1996), Frey, Pommerehne and Gygi (1993), Yezer, Goldfarb and Poppen (1996), Laband and Beil (1999) and Frank and Schulze (2000).

2. Multinominal logit analysis of the estimated models does not change the results at all and is therefore not reported here.

\section{References}

Carter, J. R. \& Irons, M. D. (1991). “Are Economists Different, and If So, Why?” Journal of Economic Perspectives. 5, 171-177.

Frank, R. H., Gilovich, T., \& Regan, D. T. (1993). “Does Studying Economics Inhibit Cooperation?” Journal of Economic Perspectives. 7, 159-171.

Frank, R., Gilovich, T., \& Regan, D. T. (1996). “Do Economists Make Bad Citizens?” Journal of Economic Perspectives. 10, 187-192.

Frank, B. \& Schulze, G. G. (2000). “Does Economics Make Citizens Corrupt?” Journal of Economic Behavior and Organization. 43, 101-113.

Frey, B. S., Pommerehne, W. W., \& Gygi, B. (1993). "Economics Indoctrination or Selection? Some Empirical Results.” Journal of Economic Education. 24, 271-281.

Laband, D. N. \& Beil, R. (1999). “Are Economists More Selfish Than Other 'Social' Scientists?” Public Choice. $100,85-100$.

Marwell, G. \& Ames, R. E. (1981). "Economists Free Ride, Does Anyone Else? Experiments on the Provision of Public Goods IV.” Journal of Public Economics. 15, 295-310.

Yezer, A. M., Goldfarb, R. S., \& Poppen, P. J. (1996). "Does Studying Economics Discourage Cooperation? Watch What We Do, Not What We Say or How We Play.” Journal of Economic Perspectives. 10, 177-186. 